
Military Technical College
Kobry El-Kobbah, Cairo, Egypt.

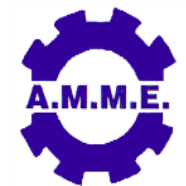
$18^{\text {th }}$ International Conference on Applied Mechanics and Mechanical Engineering.

\title{
APPLICATION OF SINGLE MINUTE EXCHANGE OF DIE ON MASS PRODUCTION COMPANY
}

\author{
S. A. Salah ${ }^{1}$ and N. Sobhi ${ }^{2}$
}

\begin{abstract}
Lean manufacturing philosophy is continually strive to eliminate the nun-value added activities, minimize the delivery cycle time and improve the quality of products. Most manufacturing companies adopt lean in order to meet customer expectations and become more competitive in the market. Implementation of Lean enterprise is an efficient and effective way to reduce the cost of the enterprise without incurring high capital expenditures. SMED is a popular lean tool used for dramatically reducing the set-up time for the machine, which is a set of techniques enabling for the replacement of tooling or set a production line in less time than 10 minutes. This paper focuses on implementing SMED methodology in a mass production company for food industries in order to reduce changeover time. The objectives of this paper are decreasing the setup times of the production line to enable the production flexibility and increase the maneuverability between different products according to customer needs. This paper monitoring carefully all production processes to identify all wasted time between processes and find ways to eliminate or decrease it. The achieved results indicate that implementation of SMED in the company has a significant impact on decreasing the setup times and increasing the total productivity and the net profit. The changeover time reduced by $25 \%$, and the OEE increased from $48 \%$ to $70 \%$, also, the sales opportunities increased by 465,600 EGP per year.
\end{abstract}

\section{KEY WORDS}

Lean production, Single Minute Exchange of Die (SMED), OEE, improve the productivity.

1 Dr., Dept. of Industrial System Engineering, October University for Modern Science and Arts, Cairo, Egypt. Email: ssalaheldein@msa.eun.eg.

2 Professor Dr., Dean of Faculty of Engineering, October University for Modern Science and Arts, Cairo, Egypt. Email: nahed.sobhi@gmail.com. 


\section{INTRODUCTION}

Globalization world challenge the manufacturers to find ways to reduce the process time in order to improve operating performance and product quality. Most companies adopting lean production concepts to remain competitive in the market. The core idea of lean manufacturing is actually quite simple; relentlessly work on eliminating wastes from the manufacturing process. These wastes have a direct impact on costs; they are all non-value adding operations. The changeover is considered a main type of wastes; it affects the availability and utilization of the machine. In Industrial environments, SMED is a system for dramatically reducing the time it takes to complete equipment changeovers. The essence of the SMED system is to convert as many changeover steps as possible to "external" (performed while the equipment is running), and to simplify and streamline the remaining steps. SMED was developed by Shigeo Shingo, a Japanese industrial engineer who was extraordinarily successful in helping companies dramatically to reduce their changeover times. Shingo observed that a lot of time was being misused when switching from a product to another. In designing the SMED scheme, he set up improvements which provide a lot of benefits in the industry [1].

However, food manufacturing is a processing industry which means the application of lean will pose a greater challenge. This is due to the unique features of the food industry such as the inflexibility of the machines, long changeover times, and the complexity of the resources [2]. According to [3], the lean methodology can be applied in the food processing industry if it was adjusted according to its constraints to achieve faster throughputs, and reduce inventories. Lean manufacturing is defined as a system which utilizes less input to create the same output while delivering increased value to the customer [4].The identification and elimination of wastes is the cornerstone of the lean philosophy. This paper applied the SMED methodology in a food industry company to reduce changeover time. This food industry company dealing with manufacturing a mass production of many kinds of biscuits and have many thousands of customers.

\section{LEAN PRODUCTION PHILOSOPHY}

Lean organizations are able to be more responsiveness to market trends and, provide products and services less expensively than their non-lean counterparts. the implementation of lean manufacturing in different types of industries was studied and concluded that lean is an effective tool to eliminate waste; inefficiency, reducing the production costs, improving quality and reliability, and speeding up cycle times [5]. The goal of lean is to improve the organization's performance that make a competitive difference, by drawing employees into the hunt to eliminate unneeded activities and other forms of operational waste [6].

\section{SMED Methodology}

SMED is a popular lean tool for shortening the machine set-up time. Shingo defined SMED as a set of techniques for the replacement of tooling or set a production line in less time than 10 minutes. The basic premise of this method is a marked decrease the size of production batches in order to adjust production to the constantly changing according to customer's demand. The needs to shorten the changeover 
time are very critical to determine the batch size for the production [7]. SMED methodology is a set of techniques to perform the equipment's setup and changeover operations in less than ten minutes [8]. A setup or changeover represents the complete process necessary to change the production from a product to another, until it is achieved a certain production rate with accepted quality [9]. Small batch production results in a significant increase in the setup frequency and ensures adequate flexibility of the response to the customer demand [10]. The implementation of this methodology requires a previous analysis to clearly understand the changeover process, in order to know in detail each setup operation [11]. The setup operations are divided into two types: internal operations (performed while the machine is stopped) and external operations (performed while the machine is operating) [8]. Also any tasks performed during the changeover should be standardized and consequently the total time for changeover will be specific and known. This allows for the time and resources used during the hangover to be quantified and taken into account during the scheduling of the production process. The tasks performed during the changeover process can be split into two categories; internal tasks which performed when the machines are stopped and external tasks which performed while the machines are running [12]. SMED methodology is split into five stages according to Shingo [13]:

Classify activities: during this stage the activities are classified into internal, external, or unnecessary. They are performed while the machine is running or in full stop. In order to gathering information about these activities, the workers should be interviewed.

Separate activities: External activities should be moved to either the beginning or the end of the changeover process. The internal activities should be standardized to eliminate any wastes, and the activities deemed unnecessary removed completely. The operators must be trained on how to perform the tasks efficiently and according to standards; this can be achieved by using checklists to make sure the external activities are performed on time.

Convert internal activities into external activities: during this stage, an in depth analysis is conducted on the internal activities to detect any wrong assumptions and to discover ways to convert them into external activities.

Streamline and reduce internal activities: the time required to perform the internal activities should be reduced and optimized. This can be performed by applying parallel operations, and designing effective tools to help perform the activities.

Streamline and reduce external activities: all effort should be concentrated on the external activities, which done outside the changeover time and have no effect on it. Simplify the remaining internal tasks by using fixtures; locating pins or visual marks to speed up the required time to get the new parts. Perform the internal tasks in parallel. If two operators can perform tasks at the same time, the time can be reduced without increasing the number of workers required for the setup process [14] as shown in Fig. 1. Also, video recording provides a valuable view of what actually happens during the changeover. Point to point diagram (spaghetti chart) can highlight opportunities to reduce the time operators spend walking, by relocating tools, parts, and even control panels. There are different methods can be used during the implementation; $5 \mathrm{~S}$ to 
eliminate the inefficient time, group jobs in pairs and perform them in parallel, remove any adjustments, and increase number of workers.

\section{Overall Equipment Effectiveness (OEE)}

Mass production companies try to optimize the performance of their existing machines to maximize equipment reliability, minimize changeover times, and improve operator performance and consequently improve the profit. OEE is a simple tool that helps managers to measure the effectiveness of their equipment/processes. By using OEE concepts such as the six big losses (shown in table 1) the wastes can be exposed and the efficiencies of the equipment's will be improved [14]. These losses are quantified as availability, performance, and quality in order to estimate OEE as given in equation (1). OEE values of different production lines can be used for comparison, and thus highlight poor production line performance [16]. Figure 2 shows the time frame for the OEE.

OEE $=$ availability $*$ performance $*$ quality

Availability relates to time lost during operating period due to breakdowns and waiting.

Availability = operating time/ planned production time

Performance, the performance takes into account speed loss, which includes any factors that cause the process to operate at less than the maximum possible speed when running [16].

Performance $=$ Actual production /Planned production

Quality, Quality takes into account Quality Loss, which accounts for produced pieces that do not meet quality standards, including pieces that require reworking [16].

Quality = Number. of good pieces/ Number of total pieces

\section{APPLICATION OF SMED}

There are five production lines in the factory. This paper focuses on the croissant production line which has the highest number of changeovers. There are three products produced on this line, the average number of changeover is eight times per month. The elapsed time in every changeover is four hours to change from one product to another. This line is developed to produce three types of croissants; (small, medium, and large) size molto.

\section{Data Collection}

A qualitative data was collected from a food industries company. The production line of this company works for three shifts per day. The production capacity is 19,800 pieces per shift. The production are passes through nine processes; dough making, lamination, fermentation, oven, aeration tower, injection, transportation machine, metal detection, and packaging. Figure 3 shows the flow chart for the croissant 
production line. The collected data about the process time for every task during the changeover methodology are illustrated in Table 2. The changeover was observed by listing and timing all the actions done by the worker and drawing a spaghetti diagram. During the setup, there were some basic elements that need to be reviewed: planning, working method, and tooling.

\section{Identify the Internal and External Tasks}

Identify the internal and external tasks are the most important step in the implementation of SMED methodology. All activities have to be classified as external or internal based on whether they can be performed while the machine is working or not. All the tasks are done by 10 workers. The required motion time is included within each task's time. The classification of changeover tasks is represented in table 2. There are twenty-eight tasks done during the changeover process, and for simplicity, they are classified into six areas: preparation, injection, transportation $\mathrm{m} / \mathrm{c}$ and metal detector, bypass, packaging, and finally trial run.

\section{Convert Internal Tasks into External Tasks}

In order to convert internal setup times to external setup times, the main focus was on the tasks related to material handling, information gathering, cleaning, adjustments, and control. In the current state, there are only nine tasks out of twentyeight tasks can be done while the machine is working. These external tasks will be removed out of the changeover window. $70 \%$ of the tasks are internal tasks and due to safety requirements, it will be difficult to convert them into external tasks. However, the others are easy to be converted, such as the movement of the workers during performing these tasks and worker utilization.

\section{Streamline the Internal Tasks and Standardize the Steps}

Streamline the tasks means to remove unnecessary activities during the setup time, such as movement or lost time in searching for the tools. In the current state, when the worker needs more materials such as alcohol, water, and cleaning materials he goes by himself to the store and gets what he needs, which is considered as a waste of motion and time. They must assign a person to get the required tools and materials for the workers. The final steps are standardizing the setup procedures and ensure there are become like habits for the workers. To improve internal setup even further there are another three steps that should help setup to reach the wanted single digit timeframe:

Parallel operations, means the setup operations are assigned to more than one person working together to decrease the setup time.

Eliminate the adjustments for components by using numerical settings, centerlines, and reference planes.

Mechanize of activities to reduce the process time. 


\section{RESULTS AND DISCUSSION}

SMED methodology is applied in the croissant line, in order to eliminate or reduce the changeover time. Applying SMED neither requires big investments nor a lot of work. It is relatively easy to do on a low level, but more standardization and improvements require naturally more recourses. The manufacturers now need to produce the product in fast time without affecting the product quality. Some of the improvement has been implemented such as setup time is recorded and statistical analysis is generated and the differences from data before improvements are presented in table 3 . The detailed movements of workers during changeover tasks are presented in spaghetti diagram before and after improvement as shown in figure 4 and figure 5 . The benefit is obvious, some long-distance movement is eliminated and the total number of movements is reduced from 250 to $100 \mathrm{~m}$. The achieved results after implementation of SMED methodology in the production line show that; thee tasks are converted from internal to external tasks, and the total changeover time reduced from (240.35 to 179.76) minutes with total saving time 60.59 minutes. The total changeover time are calculated by areas before and after implementation of SMED methodology as shown in figure 6 . The achieved results showed that the OEE in the croissant line increased from $48 \%$ to $70 \%$ after implementation of SMED methodology. That is means the availability increased by decreasing the changeover time. Then the OEE is affected by the changeover time as shown in figure 7. The total time saving per changeover is nearly one hour, which equal eight hours per month and 96 hours per year as shown in table 4 .

\section{CONCLUSION}

This paper provides a broad perspective on studying the effect of implementing the SMED methodology in a food Industries Company. This methodology is applied in the croissant production line to propose an optimal standard procedure for changeover operations on defined machine. A Comparison of results and achievements before and after implementation were made to measure the effectiveness of SMED to reduce cycle time. The obtained results showed that the SMED methodology has great impact on reducing the changeover time and increasing the OEE. The changeover time is decreased by one hour; OEE is increased by $22 \%$ after implementation of that methodology. Also the sales size increased by 232,800 pieces per year. This achievement led to increasing the total price from sales by $465,600 \mathrm{EGP} /$ Year.

\section{REFERENCES}

[1] Lozano, J., Saenz-Díez, J. C., Martínez, E. (2016), "Methodology to improve machine changeover performance on food industry based on SMED", International Journal of Advanced Manufacturing Technology.

[2] Lopes, Freitas, and Sousa, (2015), "Application of Lean Manufacturing Tools in the Food and Beverage Industries", Journal of Technology Management \& Innovation vol.10 no.3 Santiago.

[3] Jain, R. a. (2009), "The implementation of lean manufacturing in the UK food and drink industry", International Journal of Services and Operations Management, 548-573 
[4] Womack, J.P., Jones, D.T. and Roos, D. (1990) The Machine that Changed the World, New York: Macmillan.

[5] Lonnie Wilson (2010). "How to Implement Lean Manufacturing". McGraw-Hill eBooks New York Chicago.

[6] Pratik Chikhalikar, (2015). "Implementation of lean manufacturing in an engine manufacturing unit- A review ", Int. J. Mech. Eng. \& Rob. Res. Vol. 4, No. 1.

[7] Fletcher Birmingham, James Jelinek. (2007)." Quick Changeover Simplified: The Manager's Guide to Improving Profits with SMED". Hand kook by Productivity Press.

[8] S. Shingo. (1985). "A revolution in manufacturing, the SMED system".

[9] R.I. Mclntosh, S.J. Culley, A.R. Mileham, and G.W. Owen, (2000). "A critical evaluation of Shingo's 'SMED' (Single Minute Exchange of Die) methodology", Int J Prod Res, Vol. 38, no. 11, pp. 2377-2395.

[10] D. Van Goubergen, H. Van Landeghem, (2002) "Reducing setup times of manufacturing lines", In Proceeding of International Conference on Flexible Automation and Intelligent Manufacturing, Dresden, Germany.

[11] R.M. Sousa, R.M. Lima, J.D. Carvalho, A.C. Alves, (2009). "An Industrial Application of Resource Constrained Scheduling for Quick Changeover", In Proceedings of IEEE International Conference on Industrial Engineering and Engineering Management.

[12] Lozano, J., Saenz-Díez, J. C., Martínez, E., Jiménez, E., \& Blanco, J. (2016). "Methodology to improve machine changeover performance on food industry based on SMED". The International Journal of Advanced Manufacturing Technology.

[13] Shingo, S. (1988). Non-Stock Production: The Shingo System for Continuous Improvement. Cambridge, MA: Productivity Press.

[14] Peter, K. (2009). "SMED in the process industry: improved flow through shorter product changeovers". Industrial Engineer.

[15] Berna Ulutas. (2015). "An application of SMED Methodology". World Academy of Science, Engineering and Technology. International Journal of Industrial and Manufacturing Engineering.

[16] EXOR. The Complete Guide to Simple OEE. Retrieved December 16, 2016 , from http://www.exor-rd.com. 


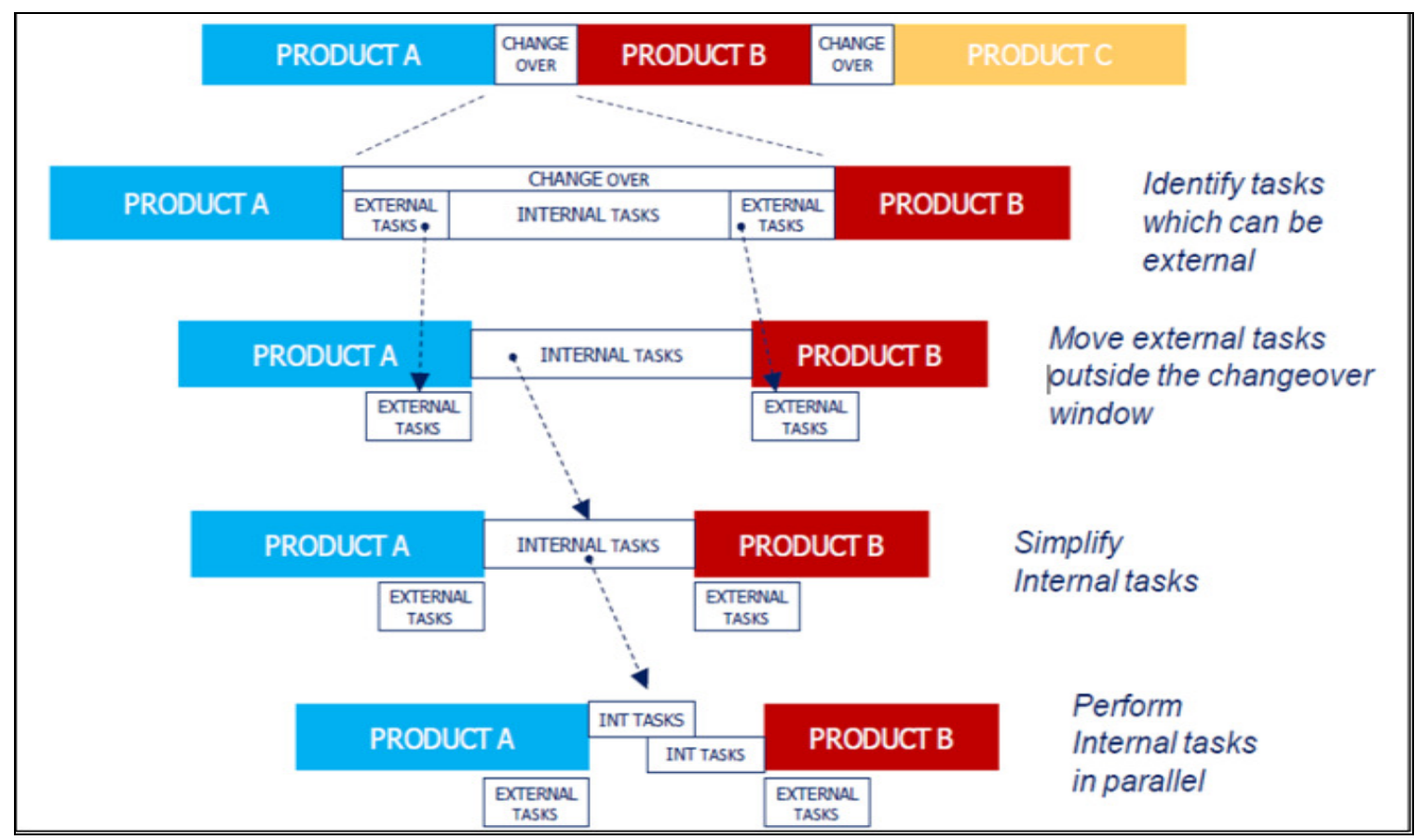

Fig. 1. Major SMED Improvement Steps [14].

Equipment

Six Big Losses

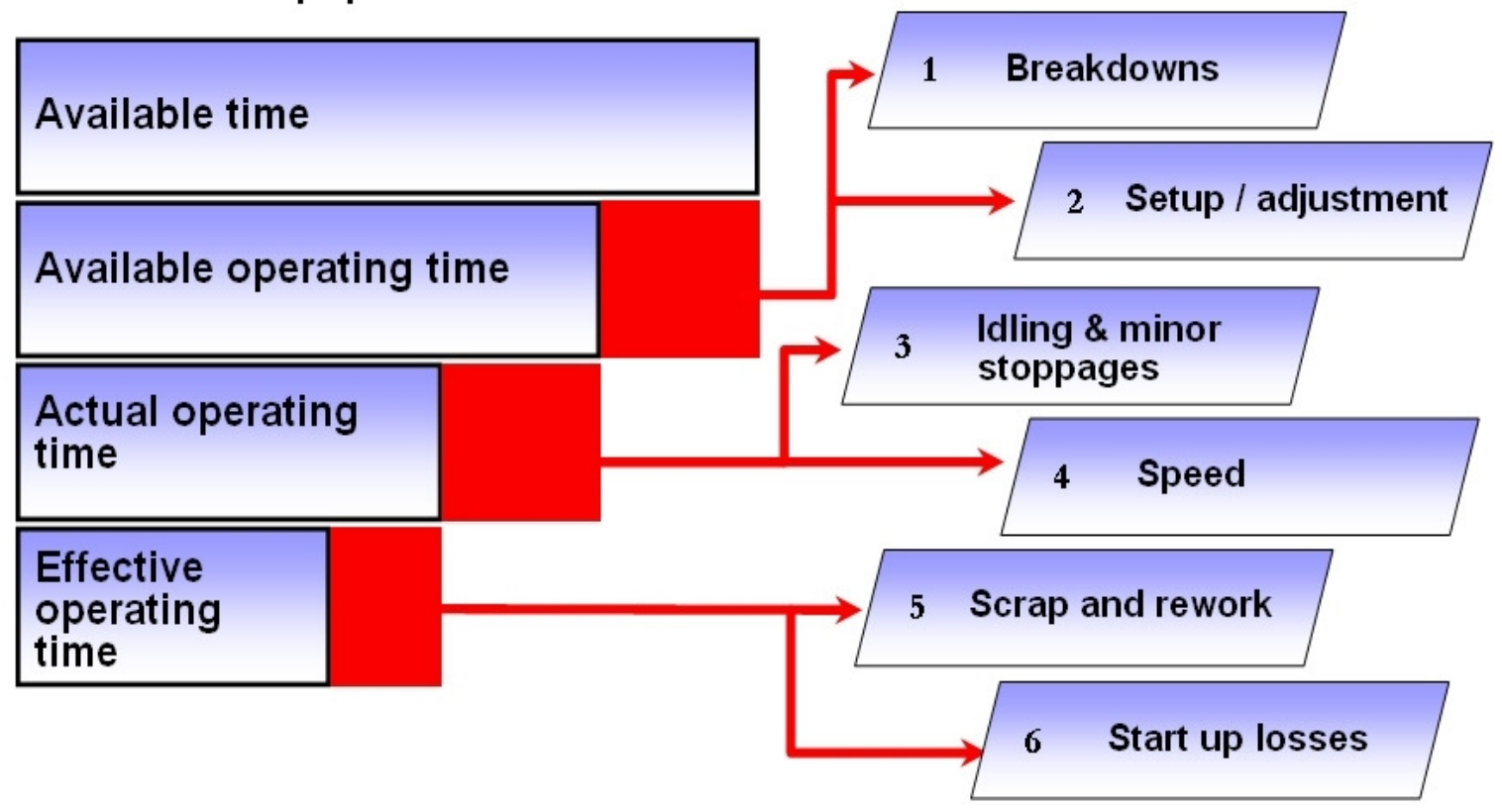

Fig. 2. OEE Time Frame [16]. 


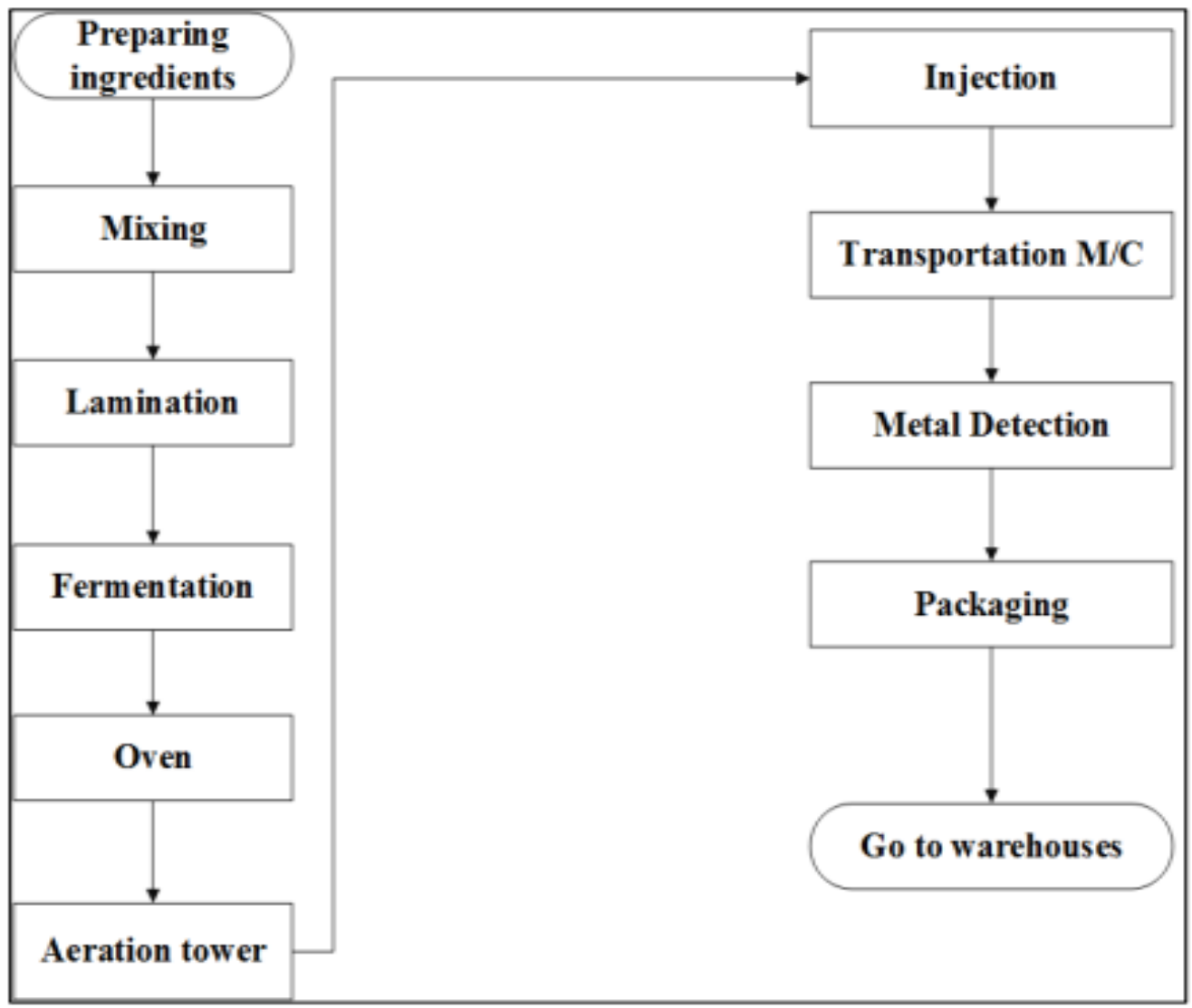

Fig. 3. Flow-chart for the croissant production line.

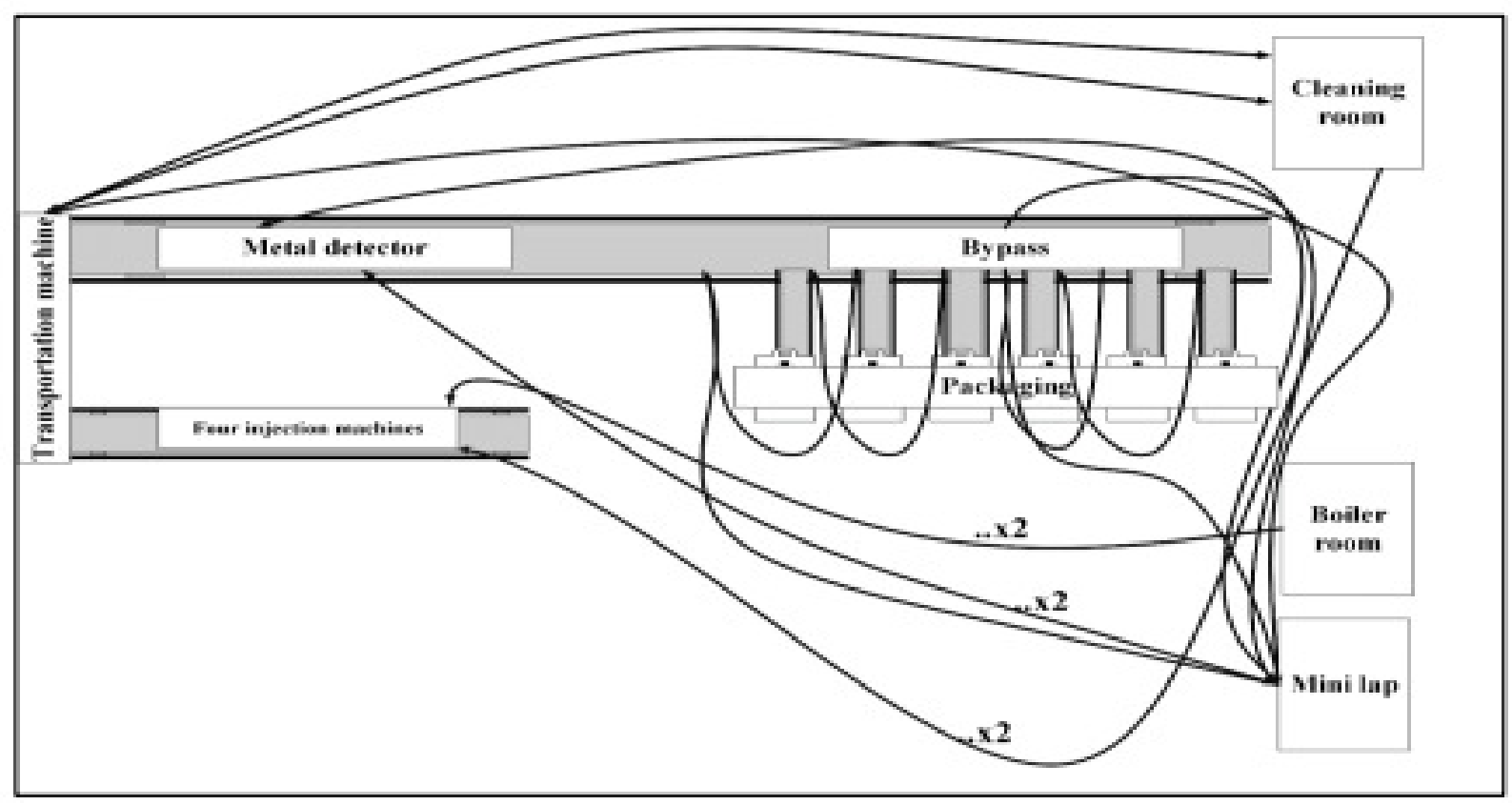

Fig. 4. Spaghetti diagram for the changeover areas before the improvements. 


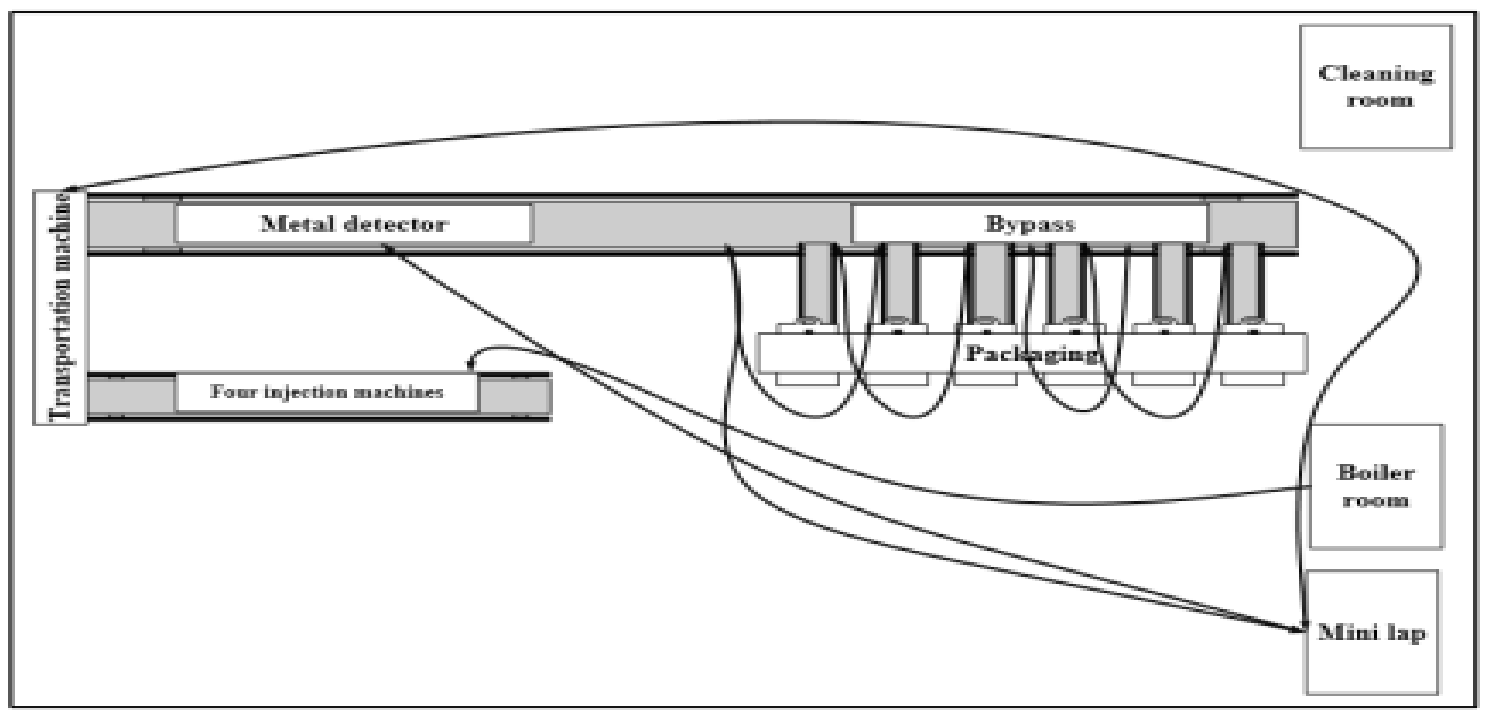

Fig. 5. Spaghetti diagram for the changeover areas after the improvements.

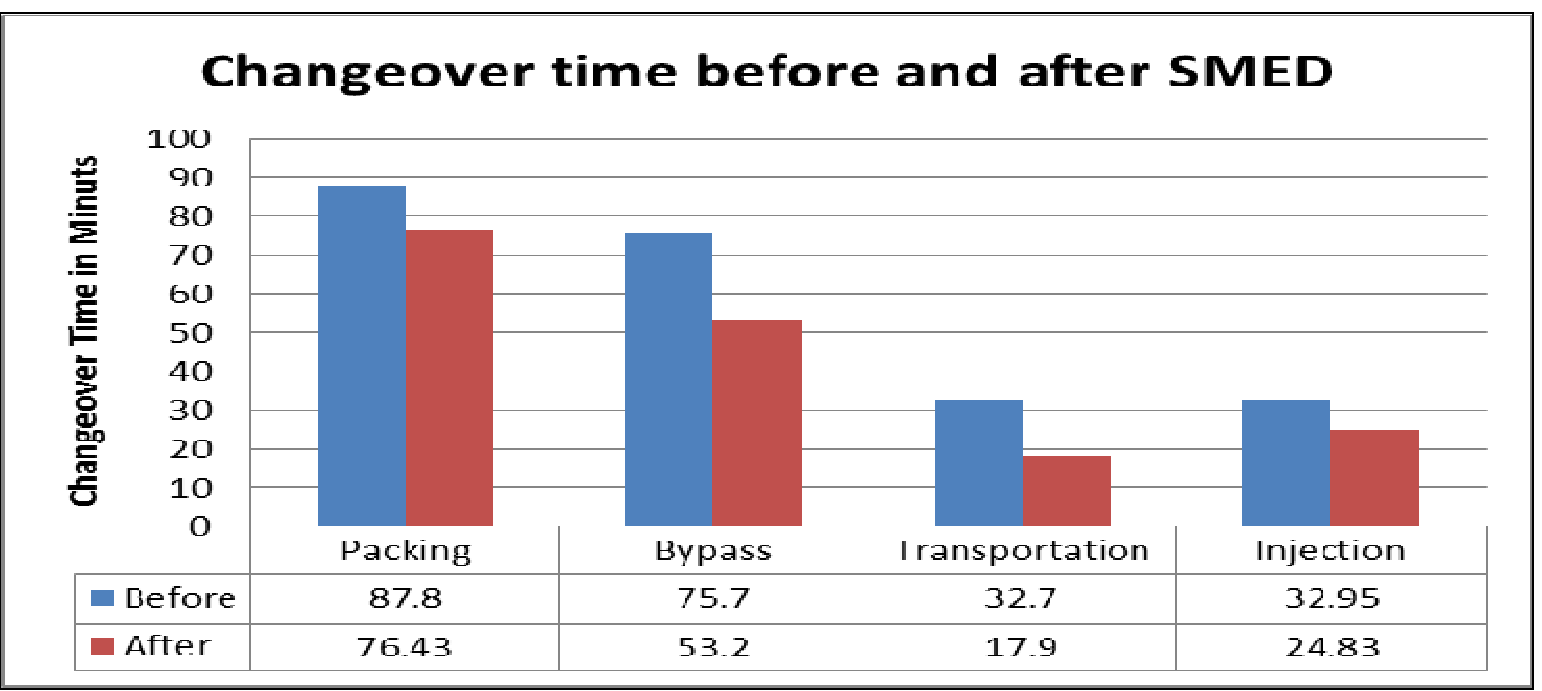

Fig. 6. Average Changeover Time by areas before and after the improvements.

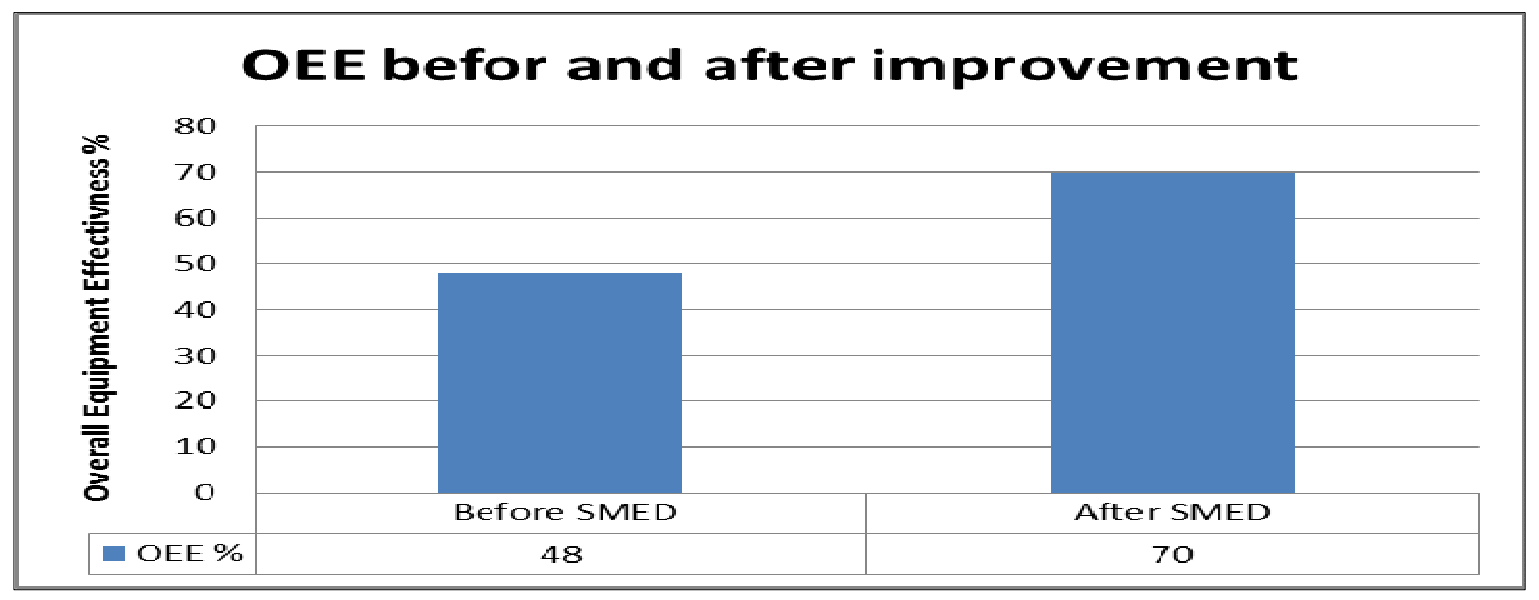

Fig. 7. OEE before and after the improvements. 
Table 1. Six Big Losses [16].

\begin{tabular}{|c|c|c|l|}
\hline $\begin{array}{l}\text { Six big loss } \\
\text { category }\end{array}$ & $\begin{array}{c}\text { OEE loss } \\
\text { category }\end{array}$ & OEE factors & \multicolumn{1}{|c|}{ Event Examples } \\
\hline $\begin{array}{l}\text { Setup and } \\
\text { adjustments }\end{array}$ & Down time loss & Availability & $\begin{array}{l}\text { Setup/changeover Material. } \\
\text { Material / Operator shortages. } \\
\text { Major adjustments. }\end{array}$ \\
\hline Breakdown & Down time loss & Availability & $\begin{array}{l}\text { Tools failures. } \\
\text { Unplanned maintenance. } \\
\text { General breakdown. } \\
\text { Equipment failures. }\end{array}$ \\
\hline Minor stops & Speed loss & Performance & $\begin{array}{l}\text { Obstructed product flow. } \\
\text { Component jams. } \\
\text { Sensor/delivery blocked. } \\
\text { Cleaning/checking. }\end{array}$ \\
\hline Reduced speed & Speed loss & Performance & $\begin{array}{l}\text { Rough running. } \\
\text { Under } \\
\text { capacity. } \\
\text { Equipment wear. } \\
\text { Operator inefficient. }\end{array}$ \\
\hline Startup rejects & Quality loss & Quality & $\begin{array}{l}\text { Scrape/Rework. } \\
\text { In process damage. } \\
\text { Incorrect assembly. }\end{array}$ \\
\hline Production rejects & Quality loss & Quality & $\begin{array}{l}\text { Scrape/Rework. } \\
\text { In process damage. } \\
\text { Incorrect assembly. }\end{array}$ \\
\hline
\end{tabular}


Table 2. Classification of Changeover Tasks.

\begin{tabular}{|c|c|c|c|c|}
\hline Area & $\begin{array}{l}\text { Task } \\
\text { Number }\end{array}$ & Task description & $\begin{array}{l}\text { Time } \\
\text { (min.) }\end{array}$ & $\begin{array}{l}\text { Internal/ } \\
\text { External }\end{array}$ \\
\hline 을 & 1 & $\begin{array}{l}\text { Bring the required equipment and cleaning material from } \\
\text { the store }\end{array}$ & 4.2 & Internal \\
\hline \multirow{7}{*}{ 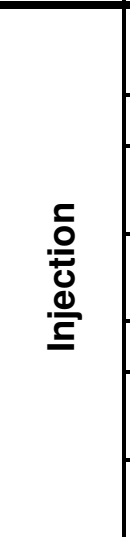 } & 2 & $\begin{array}{l}\text { Stop injector, remove flavor tank, prepare the required } \\
\text { tools, and put the hot water tank. }\end{array}$ & 2.3 & Internal \\
\hline & 3 & Release needles from all injectors & 2.7 & Internal \\
\hline & 4 & $\begin{array}{l}\text { Take the needles to the cleaning room and clean them } \\
\text { by using hot water }\end{array}$ & 20 & Internal \\
\hline & 5 & $\begin{array}{l}\text { Clean injectors } 1 \& 2 \text { by passing hot water through the } \\
\text { pipes and the machine. }\end{array}$ & 22 & External \\
\hline & 6 & Clean injectors $3 \& 4$ by the same method & 24 & External \\
\hline & 7 & $\begin{array}{l}\text { Sears some parts in the machine by using air pipes (time } \\
\text { for } 4 \text { injectors). }\end{array}$ & 4.7 & Internal \\
\hline & 8 & Install the needles and other parts for the four injectors. & 3.25 & Internal \\
\hline \multirow{7}{*}{ 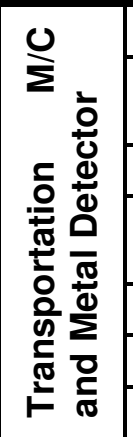 } & 9 & Release needle head, two heads, 4 bolts for each head. & 1.3 & Internal \\
\hline & 10 & $\begin{array}{l}\text { Clean the belts and the rollers under transportation } \\
\text { machine }\end{array}$ & 2 & Internal \\
\hline & 11 & Clean rollers under metal detector. & 20 & Internal \\
\hline & 12 & $\begin{array}{l}\text { Clean metal detector belts by using only water and } \\
\text { cleaning materials }\end{array}$ & 15.5 & External \\
\hline & 13 & Cleansing transportation machine belt by using alcohol. & 1.2 & Internal \\
\hline & 14 & Sanitizing all belts in this area by using barfly & 6.4 & Internal \\
\hline & 15 & Cleansing all belts in this area by using alcohol. & 1.8 & Internal \\
\hline \multirow{6}{*}{ 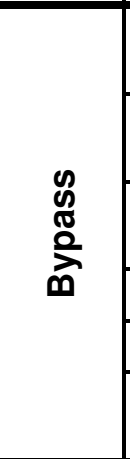 } & 16 & $\begin{array}{l}\text { Release doors of bypass machine and other related } \\
\text { parts to allow the worker clean the rollers ( } 15 \text { doors). }\end{array}$ & 20.7 & Internal \\
\hline & 17 & $\begin{array}{l}\text { Cleaning the rollers and other related parts under the } \\
\text { bypass belt by using water and cleaning materials }\end{array}$ & 18 & Internal \\
\hline & 18 & $\begin{array}{l}\text { Cleaning bypass belts by using water and cleaning } \\
\text { material. }\end{array}$ & 20.3 & External \\
\hline & 19 & Sanitizing all belts in this area by using belfry & 18 & Internal \\
\hline & 20 & Sanitizing all belts in this area by using alcohol & 32 & External \\
\hline & 21 & $\begin{array}{l}\text { Put doors under bypass, put the containers under } \\
\text { bypass, and ensure that all parts in the right position }\end{array}$ & 19 & Internal \\
\hline \multirow{6}{*}{ 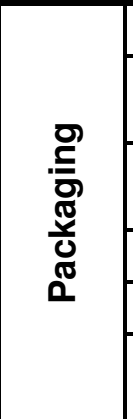 } & 22 & Remove packaging rollers from the six machines. & 7 & Internal \\
\hline & 23 & $\begin{array}{l}\text { Removing small belts of the bypass and some parts to } \\
\text { clean }\end{array}$ & 20 & Internal \\
\hline & 24 & $\begin{array}{l}\text { Use air pipes to remove small pieces that are stacked } \\
\text { between machines parts }\end{array}$ & 15.3 & Internal \\
\hline & 25 & Use brush to clean packaging machine & 6.3 & Internal \\
\hline & 26 & Put the bypass's small belts and parts that removed & 8.2 & Internal \\
\hline & 27 & $\begin{array}{l}\text { Put packaging rollers and other parts. Test and prepare } \\
\text { the machines (one worker). }\end{array}$ & 31 & Internal \\
\hline $\begin{array}{l}\text { Trial } \\
\text { run }\end{array}$ & 28 & $\begin{array}{l}\text { Return all equipment to their places and prepare to } \\
\text { restart the line }\end{array}$ & 7 & Internal \\
\hline
\end{tabular}


Table 3. Changeover time before and after SMED implementation.

\begin{tabular}{|c|c|c|c|c|c|c|}
\hline \multirow{3}{*}{ Area } & \multirow{3}{*}{$\begin{array}{c}\text { Task } \\
\text { No. }\end{array}$} & \multirow{3}{*}{ Task description } & \multicolumn{4}{|c|}{ Actual Time (min.) } \\
\hline & & & \multicolumn{2}{|c|}{ Internal } & \multicolumn{2}{|c|}{ External } \\
\hline & & & Before & After & Before & After \\
\hline 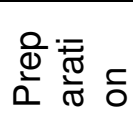 & 1 & $\begin{array}{l}\text { Bring the required equipment and cleaning material from } \\
\text { the store }\end{array}$ & 4.2 & 3.4 & & \\
\hline \multirow{7}{*}{ 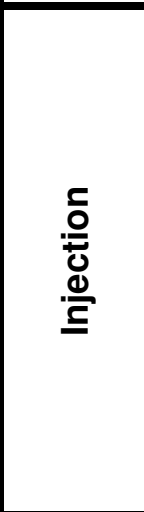 } & 2 & $\begin{array}{l}\text { Stop injector, remove flavor tank, prepare the required } \\
\text { tools, and put the hot water tank. }\end{array}$ & 2.3 & 1.3 & & \\
\hline & 3 & Release needles from all injectors & 2.7 & 1.5 & & \\
\hline & 4 & $\begin{array}{l}\text { Take the needles to the cleaning room and clean them } \\
\text { by using hot water }\end{array}$ & 20 & 15.7 & & \\
\hline & 5 & $\begin{array}{l}\text { Clean injectors } 1 \& 2 \text { by passing hot water through the } \\
\text { pipes and the machine. }\end{array}$ & & & 22 & 22 \\
\hline & 6 & Clean injectors $3 \& 4$ by the same method & & & 24 & 24 \\
\hline & 7 & $\begin{array}{l}\text { Sears some parts in the machine by using air pipes (time } \\
\text { for } 4 \text { injectors). }\end{array}$ & 4.7 & 4 & & \\
\hline & 8 & Install the needles and other parts for the four injectors. & 3.25 & 2.33 & & \\
\hline \multirow{7}{*}{ 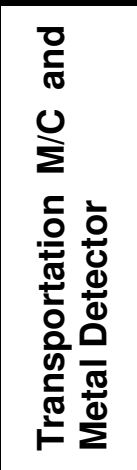 } & 9 & Release needle head, two heads, 4 bolts for each head. & 1.3 & 1.3 & & \\
\hline & 10 & $\begin{array}{l}\text { Clean the belts and the rollers under transportation } \\
\text { machine }\end{array}$ & 2 & 1.6 & & \\
\hline & 11 & Clean rollers under metal detector. & 20 & 15 & & \\
\hline & 12 & $\begin{array}{l}\text { Clean metal detector belts by using only water and } \\
\text { cleaning materials }\end{array}$ & & & 15.5 & 15.5 \\
\hline & 13 & $\begin{array}{l}\text { Cleansing transportation machine belt by } \\
\text { using alcohol }\end{array}$ & 1.2 & - & - & 1.2 \\
\hline & 14 & Sanitizing all belts in this area by using Barfly & 6.4 & - & - & 6.4 \\
\hline & 15 & Cleansing all belts in this area by using alcohol. & 1.8 & - & - & 1.8 \\
\hline \multirow{6}{*}{ 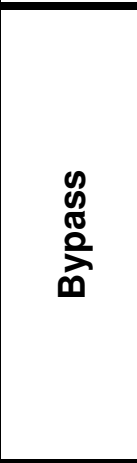 } & 16 & $\begin{array}{l}\text { Release doors of bypass machine and other related } \\
\text { parts to allow the worker clean the rollers ( } 15 \text { doors). }\end{array}$ & 20.7 & 19.2 & & \\
\hline & 17 & $\begin{array}{l}\text { Cleaning the rollers and other related parts under the } \\
\text { bypass belt by using water and cleaning materials }\end{array}$ & 18 & 15 & & \\
\hline & 18 & $\begin{array}{l}\text { Cleaning bypass belts by using water and cleaning } \\
\text { material. }\end{array}$ & & & 20.3 & 15.3 \\
\hline & 19 & Sanitizing all belts in this area by using Barfly & 18 & - & - & 18 \\
\hline & 20 & Sanitizing all belts in this area by using alcohol & & & 32 & 32 \\
\hline & 21 & $\begin{array}{l}\text { Put doors under bypass, put the containers under } \\
\text { bypass, and ensure that all parts in the right position }\end{array}$ & 19 & 19 & & \\
\hline \multirow{6}{*}{ 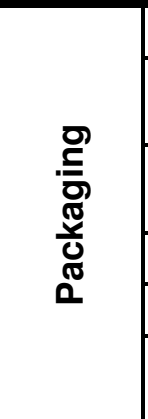 } & 22 & Remove packaging rollers from the six machines. & 7 & 5 & & \\
\hline & 23 & $\begin{array}{l}\text { Removing small belts of the bypass and some parts to } \\
\text { clean }\end{array}$ & 20 & 18 & & \\
\hline & 24 & $\begin{array}{l}\text { Use air pipes to remove small pieces that are stacked } \\
\text { between machines parts }\end{array}$ & 15.3 & 12.3 & & \\
\hline & 25 & Use brush to clean packaging machine & 6.3 & 4.4 & & \\
\hline & 26 & Put the bypass's small belts and parts that removed & 8.2 & 7.33 & & \\
\hline & 27 & $\begin{array}{l}\text { Put packaging rollers and other parts. Test and prepare } \\
\text { the machines (one worker). }\end{array}$ & 31 & 29.4 & & \\
\hline $\begin{array}{l}\text { Trial } \\
\text { run }\end{array}$ & 28 & $\begin{array}{l}\text { Return all equipment to their places and prepare to } \\
\text { restart the line }\end{array}$ & 7 & 4 & & \\
\hline
\end{tabular}


Table 4. The increase in sales size after improvement.

\begin{tabular}{|l|c|}
\hline \multicolumn{1}{|c|}{ Items } & Quantity \\
\hline Time saved/changeover, [Hrs] & 1 \\
\hline Time saved/Month, [Hrs] & 8 \\
\hline Time saved/Year, [Hrs] & 96 \\
\hline Production /Hour, [pieces] & 2425 \\
\hline Increase sales/Year, [pieces] & 232,800 \\
\hline Price / piece, [EGP] & 2 \\
\hline Total increase in sales price /Year, [EGP] & 465,600 \\
\hline
\end{tabular}

